\title{
TRACEABILITY OF PEACHES FROM INTEGRATED PRODUCTION IN SOUTH BRAZIL
}

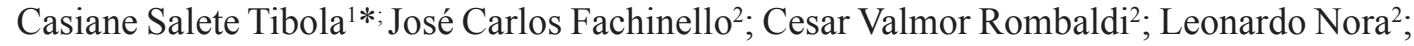 \\ Andrea de Rossi Rufato ${ }^{2}$; Leo Rufato ${ }^{3}$

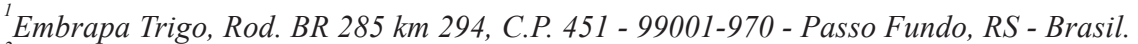 \\ ${ }^{2}$ UFPEL/FAEM - C.P. 354 - 96010-900 - Pelotas, RS - Brasil. \\ ${ }^{3}$ UDESC/CAV - 88.520-000 - Lages, SC - Brasil. \\ *Corresponding author <casiane@cnpt.embrapa.br >
}

\begin{abstract}
Traceability is becoming the most effective method to provide a safer food chain and connection producers to consumers. This paper report the application and validation of a traceability system on the production chain of peaches, according the rules for Integrated Production of Peach (IP) and a Hazard Analysis and Critical Control Point (HACCP) systems. The harvesting plots were discriminated using a Global Positioning System (GPS) device. The horticultural practices were registered in a field book according to the Brazilian IP rules. Boxes to transport the fruit, from the orchard on, were barcode labelled to identify the fruits in terms of origin (orchard and harvesting plot), cultivar, quality, picking date and time. Arriving in the factory, by an optical barcode reading device, the fruits in the boxes were assigned to homogeneous batches. Peach cans were labelled according to their corresponding batch number and monitored based on physical and chemical analysis as preconized by the IP rules and HACCP system. An electronic data base was set up and placed over the Internet. Using the batch number, the history of each peaches can could be traceable back to their harvesting plot. Therefore, manufacturers can monitor the product at any time and take any necessary action, such as product recall and/or product reprocessing.
\end{abstract}

Key words: traceability, quality, food safety

\section{RASTREABILIDADE DE PÊSSEGOS PRODUZIDOS NO SISTEMA DE PRODUÇÃO INTEGRADA NO SUL DO BRASIL}

\begin{abstract}
RESUMO: A rastreabilidade está se tornando o método mais efetivo para assegurar uma cadeia alimentar mais segura e conectar produtores e consumidores. Nesse trabalho relatamos a aplicação e validação de um sistema de rastreabilidade na cadeia produtiva do pêssego, de acordo com as Normas Brasileiras para Produção Integrada de Pêssego (PIP) e Análises de Perigos e Pontos Críticos de Controle (APPCC). As parcelas de colheita foram discriminadas utilizando-se um aparelho de GPS (Global Positioning System). As práticas horticulturais foram registradas no caderno de campo, de acordo com as normas da PIP. As caixas para transportar as frutas, desde a lavoura, foram etiquetadas com código de barra para identificar as frutas em termos de origem (pomar e parcela de colheita), cultivar, qualidade, data e hora de colheita. $\mathrm{Na}$ indústria, utilizando-se um leitor ótico de código de barras, as frutas de cada caixa foram alocadas para um determinado lote homogêneo para fins de processamento. As latas de pêssego foram etiquetadas com o número do lote homogêneo correspondente, foi monitorado com base em análise físicas e químicas, de acordo com as regras da PIP e da APPCC. Uma base d e dados eletrônica foi construída e disponibilizada através da Internet. Utilizando-se o número do lote, foi possível obter todas as informações desde a(s) parcela(s) de colheita correspondente(s) a uma determinada lata de pêssego.

Palavras-chave: rastreabilidade, qualidade, alimento seguro
\end{abstract}

\section{INTRODUCTION}

In the food business assurance of quality is becoming a central part of all activities focusing on safety. The consumer's interest in a better life quality is inducing the development of technologies that protect the environment and their health. This behaviour contributes for the production of safer foods of recognized quality. According to the con- cepts of Integrated Production (IP), traceability systems and Hazard Analysis and Critical Control Point (HACCP), competitiveness is decisive to the primary sector (Fachinello et al., 2004; Regattieri et al., 2007). Recent food safety records show that about seven million people per year are affected by foodborne illnesses. As a result, consumers require suitable information about food origin, composition and safeness, which can only be guaranteed 
by an efficient tracking-tracing system (Sarig et al., 2006; Regattieri et al., 2007).

The consumers concern about food safety and quality has led to the use of the new buzzword: 'traceability', triggered primarily by consumers concerns about Bovine Spongiform Encephalopathy (BSE), dioxin in chicken feed, Salmonella and Listeria in fresh produce food and bioengineered food products, among other problems (Kuiper et al., 2004; Nilsson et al., 2004). Since then, traceability has become more than a food production buzzword, and is now a necessary component of the food production process (Sarig et al., 2006).

The total Brazilian peach production is around 150 thousand tons per year. In 1999 a project was initiated in order to establish the Integrated Peach Production (IP), which was adopted by 105 peach producers, corresponding to a production of 6.240 tons from 520 ha in 2005/2006 (Andrigueto \& Kososki, 2004). The aim of this study was to establish, evaluate and validate a traceability system in a canned peach production chain, supported by the IP rules for peaches and by the HACCP rules, therefore in a process where good manufacture practices are expected to be in place.

\section{MATERIAL AND METHODS}

The project was started in 2002 with five peach growers and one canning factory. Nowadays, two canning industries and 25 peach producers from a fruit growers association participate on the project. The peaches for the present study were produced and processed according to the IP rules. The main characteristics of the orchards comprised in the present study are in Table 1. The assistance to establish the Integrated Peach Production and the Traceability System comprised monthly visits to the orchards and daily visits to the factory while the peach industrial processing period.

\section{Orchard traceability}

Each farm was individually identified and the orchards were divided and characterized in plots according to their cultivar and implantation year. A GPS (Global Positioning System) was used to locate the plots. Plots were described on the field book by trained fruit growers and/or agronomy technicians. The description of each plot comprised: (i) plot identification; (ii) weekly monitoring of oriental fruit moth (Grapholita molesta Busk), (iii) fruit fly (Anastrepha fraterculus Wied) and other pests; (iv) agrochemical application of legally authorized agrochemicals for pest and diseases control; (v) fertilizers application; (vi) pruning and thinning; (vii) soil management and mowing or weeding of herbaceous plants under the tree canopy; (viii) agrochemicals storing and (ix) disposal of empty agrochemical containers. Risk assessment in the peach production (Table 2) was performed and preventing and monitoring procedures were established according to IP rules for peaches (Fachinello et al., 2003). During the harvest, fruit boxes were barcode labelled to identify the corresponding fruit producer, plot, cultivar, date and the time of picking.

\section{Factory traceability}

In the factory batches including at least 100 fruit boxes were prepared. The size of the batches was adequate according to the production line. The batches preferably included similar quality peaches from the same cultivar and orchard. Only eventually it was necessary to include fruit from different quality and/or from more than one orchard. The labels were read using a barcode optical reading device in order to assign the fruits to a specific processing batch. The information stored in the barcode reading device was trans-

Table 1 - Main aspects of the peach production in the farms that supplied the fruit, according to the integrated production rules, for a study aiming the implementation of a traceability system in the production of canned peaches in Pelotas, RS, Brazil, in 2002 to 2005 years.

\begin{tabular}{lccc}
\hline \multirow{2}{*}{ Main aspects of peach production } & \multicolumn{2}{c}{ Farm area (ha) } \\
\cline { 2 - 3 } & $0-5$ & $6-10$ & 14 \\
\hline number of fruit growers & 5 & 6 & $75 \%$ \\
farm area occupied with peach orchard & $85 \%$ & Productivity (t ha $\left.{ }^{-1}\right)$ & $56 \%$ \\
farm area occupied with peaches integrated production & $40 \%$ & $10-15$ & $>15$ \\
\hline & & 12 & 9 \\
number of fruit growers & 4 & 10 & permanent employees \\
predominant labour force & family workers & seasonal employees & 9 \\
number of fruit growers & 5 & 11 & $98 \%$ \\
\hline
\end{tabular}


ferred to an electronic database for storage and analysis by means of a specialized computer program (Fruit tracing $^{\circledR}$ ) developed for the present study. Each processed batch fruit passed the processing line with a five min interval between them. The quality control at the factory was performed according to the IP rules for peaches including several measurements: firmness and total soluble sugar content in the fruit ( ${ }^{\circ}$ Brix), sodium hydroxide concentration and temperature of the peeling solution, sugar content in the syrup, sterilization temperature and time, can lid riveting quality, gross weight, net weight; drained net weight, can internal vacuum and other information to access the quality and safety of the canned peaches. The risk assessment performed in the postharvest operations is described in Table 3.

\section{Electronic data handling}

A computer program denominated Fruit tracing ${ }^{\circledR}$ was developed for electronic data handling according to the main fruit classification systems and fruit canning processes used in Brazil. This computer program was designed to allow access to the stored information over the Internet by whoever in it is interested. The database generated by the Fruit tracing ${ }^{\circledR}$ allows the identification of products labelled with a pertinent barcode type EAN/UCC-128 (GS1-Belgium \& Luxembourg, 2003). This barcode has prefixes called Application Identifiers (AI's) that determine the significance and the data format and/or type and facilitates the buyers to get information about the corresponding batch for a specific food product. The barcode contains the following information: product, company, category (special or extra), drained net weight, date and time of processing, expiring date, and batch number. Each company has a database including quality control, production reports and documents about the origin of raw matter. This makes it possible to obtain detailed information about processed peaches according to each cultivar, plot and/or farmer. In electronic tracking and tracing systems, the EAN.UCC System (GS1-Belgium\&Luxembourg, 2003) is universally accepted as an identification and communication system that facilitates efficient global commerce and improves

Table 2 - Steps and risks monitored and registered in the field book of Integrated Peach Production. Pelotas, 2005.

\begin{tabular}{|c|c|c|}
\hline Step/local & Risk & Causes \\
\hline orchard area & biological & $\begin{array}{l}\text { orchard localization, historical of the area, fertilizers used, treatments, } \\
\text { occurrence of enteropathogenics organisms }\end{array}$ \\
\hline orchard area & chemical & previous use of the area as a chemical dump. \\
\hline agrochemical applications & chemical & $\begin{array}{l}\text { use of a not recommended active ingredient an/or incorrect doses and/or no } \\
\text { observance of the residual effectiveness. }\end{array}$ \\
\hline agrochemical applications & biological & use of contaminated water (enteropathogenics parasites and bacterias). \\
\hline chemical manures & chemical & excess of nitrogen fertilization. \\
\hline organic manures & chemical & excess of nitrates and/or heavy metals. \\
\hline crop equipment & biological & contamination by enteropathogenics parasites and/or bacterias. \\
\hline
\end{tabular}

Table 3 - Risk assessment in the production of canned peaches according to the Integrated Peach Production rules (Fachinello et al., 2003).

\begin{tabular}{lcl}
\hline Risk factors & Type of risk & Cause \\
\hline reception and classification & biological & rotten fruits. \\
pitting & physical & stone pieces remaining in the pulp. \\
peeling & chemical & sodium hydroxide residuals. \\
recipients filling & physical & presence of impurity and/or foreign material \\
recipients (cans or lids) & chemical & heavy metals and or rusted. \\
recipients (cans or lids) & physical & presence of foreign material \\
sugar & physical & impurity and/or foreign material \\
sterilization conditions & biological & sterilization failure (microorganisms' survival). \\
water & chemical & chemical substances contamination. \\
water & biological & contamination of enteropathogenic parasites and/or microorganisms. \\
cooling water bath & biological & recontamination. \\
storage, transport and retail market & chemical & can rusting. \\
storage, transport and retail market & physical & can deformation \\
\hline
\end{tabular}


the effectiveness of recording and exchanging of information between supply chain participants. This system uniquely identifies products, locations, services and assets and also includes a series of standard data structures known as Application Identifiers (AI's), which allow secondary information about a product such as batch, expiring date and batch number to be encoded (Schwägele, 2005). Besides, the information encoded in barcode label, was printed on each can including fabrication and expire dates, batch number and the word traceability.

\section{RESULTS AND DISCUSSION}

\section{Peach production - agreement with the IP rules for peaches}

The IP directives on soil management were well accepted by the fruit growers that participated in the present study. Soil conditioning and fertilization were based on soil analysis and eventually also on leaf analysis. The southern region of Rio Grande do Sul state (Brazil) is affected by strong winds. Therefore, according to the IP rules, wind barriers are recommended to decrease mechanical damage. This practice is particularly important to reduce infection by pathogens through wounded tissues and has been successfully employed. Summer pruning was not widely used by the fruit growers because it demands extra hand-work. Field days on summer pruning in demonstrative orchards was organized to encourage the fruit growers to adopt the summer pruning. Growers were oriented about the time and intensity of fruit thinning. Such practice was discussed with the fruit growers and differently used due to the absence of a pre-definition by the market of size and quality of the fruits.

For the new orchards it has been used a high density planting and the trees are trimmed as a "Y" or "V" systems, which allows a better light distribution inside the canopy, earlier production and facilitate crop treatments. However, in some orchards, due to the lack of qualified labour on summer pruning, the plants were trimmed as a "vase" system, which promotes excessive shading affecting the productivity and fruit quality.

The fruit growers were advised to apply only the legally and agronomically recommended agrochemicals, at the correct dosage, using clean water (with appropriate $\mathrm{pH}$ ), the correct and properly adjusted equipment at the right period of the day under adequate weather conditions and wearing the individual protective equipment. The agrochemical containers were properly disposed according to a Brazilian law $\left(n^{\circ} .7 .802 / 89\right)$.
After triple washing, the agrochemical containers were delivered to an officially designated collecting centre. Agrochemicals were used properly in most orchards. However, the use of agrochemicals not licensed for peach orchards, which were highly toxic or of low selectivity, was eventually observed. Examples of agrochemicals misuse on the peach orchards were deltametrin and fenthion (not a selective pesticide), dimethoate (pesticide), oxitetraclin (bactericide) and benomyl (ineffective fungicide due to resistance problems).

\section{Main limitations for the production of peaches ac- cording to the IP rules}

In the peach production, the guidelines to control pests and diseases are not sufficient to support a more rational use of agrochemicals. Spilling of agrochemicals in water sources is another important limitation in the peach production in order to comply with the IP rules. About $80 \%$ of the fruit growers do not have a safe system to refill their sprayer tanks that can prevent agrochemicals spillage in the water sources such as rivers, streams and dams. Lack of proper calibration of equipments to apply agrochemical is another common problem. As a consequence of this reductions in agrochemicals effectiveness, production losses, and an increased environmental pollution and higher costs may be observed when reapplications are performed.

In terms of pests monitoring, the obstacles are pest identification and an increase in labour costs, since monitoring must be done weekly. Although monitoring allows a rational use of agrochemicals it is necessary to increase the confidence of the growers in the pest monitoring system associated with pest control system. Agrochemical molecules that can be used legally are very limited, especially for pest control. Alternatives are not available to control neither maize weevil (Sitophilus zeamais Mots.), a common pest of stored grains that attaches peaches; nor bacterial spot, that in the high humidity and high incidence of winds years causes up to $50 \%$ of production losses.

There are many claims aiming to increase the number of allowed agrochemicals and registered active ingredients in the IP for a more efficient control of pests and diseases. Brazilian fruit growers have found difficulties to get in the foreign market because there is not a common rule between countries regarding to prohibition of certain of their active ingredients (Iba, 2003).

\section{Traceability information management}

An efficient and effective traceability system should be capable to trace the complete history of the 
product, including production conditions an added ingredients (Bertolini et al., 2006; Sarig et al., 2006; Regattieri et al., 2007). In the present study, we have noticed that the fruit grower attitude on recording information in the field book was a barrier to implement the IP rules, the HACCP and the traceability system. Frequently, important information, such as the ones related to agrochemical applications, was not recorded properly, mainly during the busiest fruit production periods. Fortunately, this behaviour is changing since in the 2005 year, the majority of fruit growers recorded the information correctly.

Peaches that arrived in the factory usually were diverse in terms of producer, production system, plot, cultivar, quality and quantity. As a basic requirement in the processing line to produce canned peaches, homogeneous batches were prepared. This was necessary because the unitary operations and the corresponding equipments need to be set according to the fruit cultivar, size and maturation stage. In addition, in order to implement the traceability system, the batches were prepared taking in account the peaches origin. After transporting the barcoded labelled boxes from one control point to another, they had to be set in a position were the labels could be accessible for reading. In addition, every time the peaches were transferred from one box to another, the barcode label had to be removed and replaced. Because this operation requires human intervention, there is room for error and inefficiency (Regattieri, 2007). Apart from that, the barcode system was considered attractive to the sector, mainly because the efficiency in collecting and transferring information to the system.

In the preparation of homogeneous batches of peaches, suitable for both the processing line and the traceability system implementation, two procedures had to be used: (i) For fruit loads of the same cultivar, class and plot, it was possible to form processing batches where the fruit could be traced back to the plot. (ii) For fruit loads from diverse growers, plots and classes, it was more difficult to get a homogeneous processing batch. In this case fruit from the same cultivar and with equivalent history were pooled to form the processing batch. It was possible to trace the fruit back to the processing batch, but not to the plot or to a specific fruit grower.

Physical, chemical, sanitary and sensorial parameters were determined for all processing batches of peaches and the results were transferred immediately to the traceability system database. Detailed information about the can, lid, sugar and sodium hydroxide used to prepare each batch of canned peaches were also included in the traceability system database. For any specific processing batch, the information recorded in the traceability system database during the fruit production and fruit processing was made accessible from a public Internet server.

A product traceability system requires the identification of all the locations from which the product originates, that is to say, where it is processed, packaged, and stocked, and so this includes every agent in the supply chain (Regattieri et al., 2007). In the factory, accessing the traceability system from a local database was possible to retrieve detailed information for each cultivar, plot and/or fruit grower, according to the processing batch identification. The availability and easy access to all these information improved the factory capability to monitor the production line and to deliver canned peaches of higher quality.

\section{CONCLUSIONS}

The implementation of a traceability system supported by the IP and HACCP was successfully used in the production of canned peaches. The increasing demands from the international and internal market for high quality and safe foods, produced under environmental friendly conditions, respecting local and international social rules and able to be traced throughout the production chain, gives no other alternative to the peach production sector in Brazil but comply with these tendencies in order to maintain and increase the competitiveness. In order to comply with these tendencies a permanent effort from both the private and governmental sectors is necessary. In the present study, the most significant results from implementing the traceability system in the production of canned peaches supported by the IP and HACCP are: (i) IP and HACCP rules were more consistently applied; (ii) the amount of useful and accessible information for the decision making process significantly increased; (iii) the quality control system was improved; (iv) attainment of competitive advantages in the market due to the increases in the product quality and credibility; (v) information was made available in silico for manufacturers to check the progress in the production and to perform recall and/or reprocessing of products if necessary; (vi) information was made available in silico for consumers, guaranteeing food quality, safety and transparency.

\section{ACKNOWLEDGMENTS}

This work was supported by Brazilian Governmental Agencies: CNPq-MCT, MAPA and CAPES-MEBrazil. 


\section{REFERENCES}

ANDRIGUeto, J.R.; KOSOSKI, A.R., Desenvolvimento e conquistas da produção integrada de frutas no Brasil. In: TREINAMENTO TÉCNICO EM PRODUÇÃO INTEGRADA DE PÊSSEGO, 1, Pelotas, RS, Brazil, 2004. Proceedings. Pelotas, RS, Brazil: Universidade Federal de Pelotas, 2004. p.1539

BERTOLINI, M.; BEVILACQUA, M.; MASSINI, R. FMECA approach to product traceability in the food industry. Food Control, v.17, n.2, p.137-145. 2006.

FACHINELlO, J.C.; COUTINHO, E.F.; MAROdIN, G.A.B.; BOTTON, M.; MIO, L.L.M.D. Normas técnicas e documentos de acompanhamento da produção integrada de pêssego. Pelotas: Universidade Federal de Pelotas, Faculdade de Agronomia Eliseu Maciel, 2003. 92 p.

FACHINELLO, J.C.; RUFATO, L.; DE ROSSI, A.; FACHINELLO, A.F.; TIBOLA, C.S. Rastreabilidade para frutas in natura e processadas no Brasil. In: CONFERÊNCIA INTERNACIONAL SOBRE A RASTREABILIDADE DE ALIMENTOS, 1., São Paulo, 2004. Proceedings. São Paulo: Ministério da Agricultura, Pecuária e Abastecimento, 2004. p.141-145

GS1-BELGIUM\&LUXEMBOURG. EAN.UCC specification for the identification and traceability of fruit, vegetables and potatoes. EAN-Belgium-Luxembourg \& EAN-International, 2003.. p.127. Available at http://www.can-trace.org/about/docs/ EANBelgiumTraceability\%20FruitVegPotato.pdf. Accessed 04 Oct. 2005.
IBA, S.K.; BRABET, C.; OLIVEIRA, I.J.D.; PALLET, D. Um panorama da rastreabilidade dos produtos agropecuários do Brasil destinados à exportação: carne, soja e frutas. 2003. Available at http://www.cendotec1.org.br/dossier/cirad/produitsbrpr.pdf. Accessed 04 Feb. 2005.

KUIPER, H.A.; KOENIG, A.; KLETER, G.A.; HAMMES, W.P.; KNUDSEN, I. Concluding remarks. Food \& Chemical Toxicology, v.42, p.1195-1202. 2004.

NILSSON, H.; TUNÇER, B.; THIDELL, A. The use of eco-labeling like initiatives on food products to promote quality assurance is there enough credibility? Journal of Cleaner Production, v.12, p.517-526. 2004.

REGATTIERI, A.; GAMBERI, M.; MANZINI, R. Traceability of food products: general framework and experimental evidence. Journal of Food Engineering, v.81, p.347, 2007.

SARIG, Y.; DE BAERDEMAKER, J.; MARCHAL, P.; AUERNHAMMER, H.; BODRIA, L.; DE NÄ̈̈S, I.A.; CENTRANGOLO, $\mathrm{H}$. The role of engineering in the process of traceability of food products. Stewart Postharvest Review, v.2, p.1-7. 2006

SCHWÄGELE, F. Traceability from a European perspective. Meat Science, v.71, p.164-173. 2005.

$\overline{\text { Received October }}$ 17, 2006

Accepted September 13, 2007 